\title{
Pemanfaatan Web Services Instagram Sebagai Media Kompetisi Publikasi Pada Website XLAwards2014
}

\author{
Mohammad Sani Suprayogi \\ Program Studi Teknik Informatika \\ Universitas Semarang \\ Semarang, Indonesia \\ yogie@usm.ac.id
}

\begin{abstract}
Abstrak-Kompetisi yang diselenggarakan secara online mulai sering dilakukan, salah satu penyelenggara adalah provider XL dengan kompetisinya yang bernama XL Awards. Tahun 2014 ini XL Awards menambahkan kategori baru yaitu Publikasi yang memungkinkan peserta mengikuti kompetisi fotografi menggunakan kamera smartphone. Instagram dipilih sebagai platform utama dan nantinya hasil karya akan ditampilkan pada website XL Awards.
\end{abstract}

Website XL Awards dibangun dengan platform WordPress yang memungkinkan penambahan fitur menggunakan plugins. Alpine PhotoTile for Instagram dipilih sebagai plugin yang menjembatani antara Instagram dan WordPress kemudian juga untuk menampilkan foto dari Instagram dengan tagar \#XLAwards2014 yang ditampilkan pada halaman WordPress.

Keywords-web services; API; instagram; wordpress;

\section{PENDAHULUAN}

Penyelenggaraan perlombaan atau kompetisi dengan memanfaatkan media Internet sudah mulai sering dilakukan, salah satunya adalah kompetisi XL Awards yang diprakarsai oleh provider telekomunikasi $\mathrm{XL}^{1}$. Kompetisi yang rutin dilakukan setiap tahun ini, mulai tahun 2014 menambahkan kategori perlombaan baru yaitu kategori Publikasi untuk melengkapi dua kategori sebelumnya, Karya Tulis dan Fotografi. Kategori Publikasi ini memberikan kesempatan kepada peserta yang menyukai bidang fotografi namun belum memiliki kamera professional. Peserta cukup menggunakan kamera pada smartphone untuk mengikuti kompetisi XL Awards 2014². Pada kompetisi ini, penulis terlibat dalam proses pembangunan landing page XL Awards 2014 yang beralamat di http://awards.xl.co.id.

Instagram dipilih sebagai platform utama untuk kategori Publikasi, menyisihkan Flickr yang pamornya sudah mulai meredup dibandingkan Instagram [1], selain itu juga faktor kehandalan Instagram yang dalam 4 tahun terakhir telah mampu untuk menampung 60 juta foto dalam sehari ${ }^{3}$ dapat meyakinkan kami bahwa Instagram cocok untuk diandalkan dalam pelaksanaan kompetisi XL Awards 2014. Instagram memiliki fungsi mirip dengan Twitter yaitu tagar (\#) supaya konten lebih terstruktur dan telah terbukti efektif untuk mengelompokkan konten berdasarkan acara tertentu [2].

Penelitian ini lebih berfokus pada proses integrasi Instagram ke dalam website XL Awards menggunakan layanan web services berupa API yang disediakan oleh Instagram ${ }^{4}$. Sebagai catatan, website XL Awards menggunakan platform Wordpress yang fleksibel untuk dikembangkan.

Paper ini terstruktur sebagai berikut: Bagian II membahas metode penelitian. Bagian III mengenai implementasi dan bagian IV merupakan hasil penelitian. Kami memberikan kesimpulan pada bagian $\mathrm{V}$.

\section{METODE PENELITIAN}

Pada tahapan ini peneliti berfokus pada dua hal, yakni optimasi Instagram sebagai platform kompetisi kategori Publikasi, selanjutnya konfigurasi Wordpress yang digunakan sebagai platform website XL Awards 2014.

\section{A. Instagram}

Seperti yang telah disinggung sebelumnya, Instagram memiliki fitur tagar (\#) yang berfungsi untuk mengelompokkan konten. Selain itu, Instagram telah memberikan saran untuk pembuatan tagar ${ }^{5}$ : spesifik, relevan, dan cermat supaya foto yang disubmit oleh peserta dapat dikelompokkan dengan mudah dan tidak tercampur dengan foto dari pengguna lain yang tidak mengikuti kompetisi XL Awards 2014.

Atas pertimbangan tersebut, maka kami memutuskan untuk menggunakan tagar \#XLAwards2014 sebagai tagar resmi untuk mengikuti kategori Publikasi sehingga menjadi syarat utama bagi peserta dan nantinya akan digunakan sebagai kata kunci untuk mengambil konten foto dari Instagram.

\section{B. WordPress}

Website XL Awards $2014^{6}$ dibangun dengan platform WordPress $^{7}$. Pertimbangan utama menggunakan WordPress adalah fleksibilitas dalam hal pengembangannya, dimana

\footnotetext{
${ }^{4}$ http://instagram.com/developer/

${ }^{5}$ https://help.instagram.com/232462026881751

${ }^{6} \mathrm{http}: / /$ awards.xl.co.id

${ }^{7}$ https://wordpress.org/about/
}

\footnotetext{
${ }^{1}$ http://www.xl.co.id/id/yang-baru/promosi/xl-awards-2014

http://awards.xl.co.id/aturan-lomba/\#publikasi

${ }^{3} \mathrm{http}: / /$ instagram.com/press/
} 
WordPress mengijinkan untuk melakukan kustomisasi pada themes dan membolehkan menambahkan fitur dengan plugins, selain itu untuk pembuatan website landing page yang membutuhkan kecepatan pemrosesan, maka WordPress secara statistik lebih baik dibandingkan dengan platform lain yang sejenis [3].

Integrasi Instagram dengan WordPress dilakukan dengan memanfaatkan plugin yang tersedia di Wordpress Plugin Directory $^{8}$. Namun untuk memilih plugin yang tepat, ada beberapa hal yang perlu diperhatikan. Faktor keamanan merupakan faktor pertama yang harus diperhatikan, mengingat kompetisi XL Awards 2014 ditargetkan akan diikuti oleh ribuan peserta. Selain itu memilih plugin yang memiliki popularitas di Wordpress Plugin Directory dapat membantu menetapkan plugin yang akan dipilih walaupun masih perlu dilakukan pengecekan lebih lanjut [4] terutama lima hal terpenting 9 : remote code execution, cross-site scripting (XSS), SQL injection (SQLI), dan PHP configuration and file system attacks.

Hasil pencarian plugin mendapatkan dua kandidat, yaitu Alpine PhotoTile for Instagram ${ }^{10}$ dan Simply Instagram ${ }^{11}$. Adapun perbandingan antara kedua plugin tersebut dapat dilihat pada Tabel 1 .

TABEl 1 PERBANDINGAN Plugin

\begin{tabular}{|c|c|c|}
\hline & Alpine PhotoTile & Simply Instagram \\
\hline Versi & 1.2 .7 .3 & 1.2 .6 \\
\hline Pembaruan Terakhir & 16 Agustus 2014 & 10 Januari 2014 \\
\hline Jumlah Download & 150.296 & 124.326 \\
\hline Average Rating & 4,5 dari 5,0 & 4,1 dari 5,0 \\
\hline
\end{tabular}

Perbandingan plugin pada Tabel 1 menunjukkan tanggal pembaruan terakhir dari Alpine PhotoTile lebih baru dan nilai average rating lebih baik dibandingkan Simply Instagram. Sehingga kami memutuskan untuk memilih plugin Alpine PhotoTile for Instagram sebagai platform untuk menangani kategori lomba Publikasi di website XL Awards 2014.

\section{IMPLEMENTASI}

Tahap implementasi pada publikasi ini melalui tiga tahap, pertama instalasi plugin Alpine PhotoTile ke WordPress, kedua melakukan koneksi plugin dengan Instagram melalui layanan API, dan ketiga menampilkan hasil koneksi menggunakan sebuah halaman di WordPress.

\section{A. Instalasi Alpine PhotoTile for Instagram}

Langkah instalasi Alpine PhotoTile di WordPress adalah sebagai berikut :

1. Dari Dashboard menuju menu Plugins $\rightarrow$ Add New.

2. Ketik pencarian Alpine PhotoTile for Instagram

3. Buka menu Plugins $\rightarrow$ Installed Plugins kemudian pilih activate pada Alpine PhotoTile for Instagram.

\footnotetext{
${ }^{8} \mathrm{https}$ //wordpress.org/plugins/

${ }^{9}$ https://www.owasp.org/index.php/PHP Top 5

${ }^{10} \mathrm{https}$ //wordpress.org/plugins/alpine-photo-tile-for-instagram/

${ }^{11}$ https://wordpress.org/plugins/simply-instagram/
}

\section{B. Koneksi Plugin dengan Instagram}

Alpine PhotoTile for Instagram mensyaratkan untuk menambahkan user Instagram melalui menu Add User Instagram supaya dapat berkomunikasi dengan Instagram. Komunikasi menggunakan API yang disiapkan oleh Instagram Developer. Langkahnya sebagai berikut :

1. Buka tab baru web browser, kemudian membuka website Instagram dan melakukan login.

2. Membuka halaman Instagram Developer dan klik menu Manage Clients.

3. Mengisi form yang tersedia, antara lain:

a. Your Website : http://awards.xl.co.id

b. Phone Number: 081234567890

c. What do you want to build with this API : A plugin for XL Awards website.

4. Meregistrasikan website XL Awards 2014 ke Instagram melalui menu Register a New Client, dengan mengisi formulir :
a. Application Name : XLAwards2014
b. Description : Lomba Publikasi XLAwards2014
c. Website : http://awards.xl.co.id
d. OAuth redirect_url
http://awards.xl.co.id/wp-admin/options- general.php?page =alpine-photo-tile-for- instagram-settings\&tab $=$ add

Setelah melakukan registrasi akan mendapatkan Client ID dan Secret ID yang berfungsi sebagai identitas untuk koneksi Instagram dengan WordPress.

5. Kembali ke Dashboard WordPress menuju menu Settings $\rightarrow$ AlpineTile:Instagram.

6. Mengisikan Client ID dan Secret ID yang telah didapatkan ke dalam form yang tersedia, selanjutnya menekan menu Add and Authorize New User.

\section{Menampilkan Data Instagram ke Halaman WordPress}

Alpine PhotoTile menggunakan metode shortcode untuk menampilkan data-data Instagram ke halaman WordPress. Shortcode ini berguna untuk melakukan kustomisasi tampilan dan filter konten yang akan ditampilkan, dalam publikasi ini kami bermaksud untuk menampilkan hanya foto yang menggunakan tagar \#XLAwards2014.

Alpine PhotoTile menyediakan fitur Shortcode Generator untuk mempermudah pembuatannya, sehingga cukup mengisikan parameter yang diinginkan, selanjutnya shortcode telah tercipta dan dapat ditempelkan ke halaman WordPress.

\section{Hasil Penelitian}

Berdasarkan konfigurasi yang telah dilakukan, kami melihat bahwa data yang muncul pada halaman kategori Publikasi XL Awards 2014 ${ }^{12}$ telah sesuai dengan keinginan. Foto yang muncul adalah foto yang memiliki informasi tagar \#XLAwards2014 dan ditampilkan sebanyak 20 foto terbaru menyesuaikan layout dan demi efisiensi sumberdaya server.

\footnotetext{
${ }^{12}$ http://awards.xl.co.id/publikasi/
} 
Foto-foto dari Instagram tersebut dikustomisasi oleh plugin Alpine PhotoTile dalam bentuk gallery foto dan ditambah fitur Lightbox ${ }^{13}$ untuk mempercantik tampilan dan menampilkan keterangan setiap foto yang disubmit oleh peserta.

\section{KESIMPULAN DAN SARAN}

Berdasarkan hasil penelitian yang telah didapatkan, maka disini kami dapat menarik kesimpulan yaitu:

1. Pemanfaatan Instagram untuk sebuah kompetisi publikasi fotografi memungkinkan untuk dilakukan dengan memanfaatkan tagar (\#).

2. Alpine PhotoTile for Instagram mempermudah konfigurasi dan koneksi antara Instagram dengan website yang berplatform WordPress.

Sebagai saran untuk penelitian selanjutnya, kami menyarankan hal-hal berikut:

1. Perlu adanya penyaringan konten supaya tidak disisipi oleh pengguna yang tidak bertanggung jawab.

2. Beban sumberdaya yang harus ditanggung oleh server setiap kali gallery foto dibuka oleh user, perlu dihitung supaya dapat dioptimasi lebih lanjut.

\section{REFERENCES}

[1] B. Jensen, "Instagram as cultural heritage: User participation, historical documentation, and curating in Museums and archives through social media," in Digital Heritage International Congress (DigitalHeritage), 2013, 2013, pp. 311-314.

[2] H. C. Chang, "A new perspective on Twitter hashtag use: diffusion of innovation theory," Proceedings of the American Society for Information Science and Technology, vol. 47, pp. 1-4, 2010.

[3] S. K. Patel, V. R. Rathod, and S. Parikh, "Joomla, Drupal and WordPress - a statistical comparison of open source CMS," in Trendz in Information Sciences and Computing (TISC), 2011 3rd International Conference on, 2011, pp. 182-187.

[4] T. Koskinen, P. Ihantola, and V. Karavirta, "Quality of WordPress Plug-Ins: An Overview of Security and User Ratings," in Privacy, Security, Risk and Trust (PASSAT), 2012 International Conference on and 2012 International Confernece on Social Computing (SocialCom), 2012, pp. 834-837.

\footnotetext{
${ }^{13}$ http://lokeshdhakar.com/projects/lightbox2/
} 